\title{
Life Cycle Impact Assessment of Airborne Metal Pollution near Selected Iron and Steelmaking Industrial Areas in China
}

\author{
Xiaoteng Zhou ${ }^{1,2 *}$, Vladimir Strezov ${ }^{1,2}$, Yijiao Jiang ${ }^{1,3}$, Xiaoxia Yang1,3, Jing He$^{2}$, Tim Evans ${ }^{1,2}$ \\ ${ }^{1}$ ARC Research Hub for Computational Particle Technology, Macquarie University, Sydney, New South Wales 2109, \\ Australia \\ ${ }^{2}$ Department of Earth and Environmental Sciences, Macquarie University, Sydney, New South Wales 2109, Australia \\ ${ }^{3}$ School of Engineering, Macquarie University, Sydney, New South Wales 2109, Australia
}

\begin{abstract}
Toxic metals in particulate matter pose a significant health risk to humans via inhalation and dermal exposure. Additionally, airborne pollution has negative impacts on terrestrial and aquatic quality as a result of atmospheric deposition. Iron and steelmaking industry is considered as a major contributor to airborne metal pollution. Given that China has been the largest steel producer and consumer since 1996, a detailed investigation of airborne metal pollution is required to assess the potential risks to both human health and ecosystem quality near iron and steelmaking areas in China. This study applied an environmental impact assessment approach to evaluate the freshwater ecotoxicity, terrestrial ecotoxicity, marine ecotoxicity and human toxicity caused by metal concentrations in $\mathrm{PM}_{1.1}, \mathrm{PM}_{1.1-2.1}$ and $\mathrm{PM}_{2.1-9.0}$ fractions. Results showed that heavy metals $\mathrm{Cu}$ and $\mathrm{Zn}$ associated with steelmaking activities were largely responsible for aquatic and terrestrial ecotoxicity. This study also found that $\mathrm{As}$ and $\mathrm{Pb}$ contamination presented the largest fraction of the impacts on human toxicity. Findings presented in this study showed that more stringent control measures are required to improve the environmental performance of the iron and steelmaking industries in China.
\end{abstract}

Keywords: $\mathrm{PM}_{1} ; \mathrm{PM}_{2.5}$; Human toxicity; Aquatic ecotoxicity; Terrestrial ecotoxicity.

\section{INTRODUCTION}

Air pollution is a by-product of the rapid economic growth with increasing global urbanization and industrialization. According to the World Health Organization, it was estimated that $91 \%$ of the global population lives in places where the air quality is below the threshold guidelines (WHO, 2018). People living under poor air quality conditions have increased potential to develop a range of pollution-related illnesses, such as heart disease, stroke, chronic obstructive pulmonary disease, lung cancer and acute respiratory infections (Cheng et al., 2019).

Particulate matter (PM), as one of the common air pollutants, is a proxy indicator of air quality due to the strong association with public health impacts (WHO, 2018; Sarkodie et al., 2019). Particles with diameters of $10 \mu \mathrm{m}$ or less $\left(\mathrm{PM}_{10}\right)$ can penetrate deep inside human lungs, while $\mathrm{PM}_{2.5}$ particles have abilities to go through lung barriers and enter the blood system (WHO, 2018). It has been evidenced that 3\% of cardiopulmonary and $5 \%$ of lung cancer deaths are associated with the global PM pollution (WHO, 2013).

\footnotetext{
* Corresponding author.

E-mail address: xiaoteng.zhou@mq.edu.au
}

One of the toxic components adhered to the PM particles is heavy metals, especially $\mathrm{As}$ and $\mathrm{Pb}$, which present high toxicity at even trace concentrations (Jiang et al., 2019). For example, clear clinic evidence of skin lesions, such as ulceration and cancers, was found for people who live at intensive high-As-containing coal burning areas (Liu et al., 2002). Airborne $\mathrm{Pb}$ was also found to be responsible for the elevated $\mathrm{Pb}$ concentrations in children blood samples (Taylor et al., 2019). Both contaminations have deleterious effects on children's neurological systems, behavioural and cognitive abilities (Calderon et al., 2001; Wright et al., 2006; Wasserman et al., 2016).

Airborne particles incorporated with toxic metals can be deposited and further pollute surface waters, such as rivers, lakes and streams (Wesely and Hicks, 2000). According to the United States Environmental Protection Agency (U.S. EPA, 2016a, b), nearly half of rivers and streams (> 40\%) as well as more than one-third of lakes in the U.S. were polluted and this fraction would be much larger in developing countries. Water pollution, such as heavy metal pollution, impairs the aquatic quality and poses a risk to plants and animals that depend on water to survive (Wilde et al., 2006; Lavery et al., 2009).

PM emissions also present a dominant contribution to terrestrial ecotoxicity (Wesely and Hicks, 2000). The airbornemetal particles can be carried to the ground as formations of 
raindrops, snowflakes or fog resulting in soil pollution. Toxic metals in soils are considered as a highly persistent pollutant due to their nondegradable property (Borggaard $e t$ al., 2009). For example, the $\mathrm{Pb}$ contamination in soil can remain up to 700 years after deposition (Semlali et al., 2004). Hence, the airborne metals also pose a significant risk to terrestrial health.

Given the high toxicity of airborne metal particles to humans and ecosystems, identifying air pollution sources is required for environmental management and remediation. Previous studies showed that the iron and steelmaking industries are important contributors to airborne metal emissions (WHO, 2007; Mohiuddin et al., 2014; Mohiuddin et al., 2016; Yang et al., 2019). Hence, this study aims to apply environmental impact assessment method to identify the key toxic metals that pose risks to freshwater ecotoxicity, terrestrial ecotoxicity, marine ecotoxicity and human toxicity near iron and steelmaking areas with high population densities in China.

\section{METHODS}

\section{Sampling Information}

Five sampling sites, including four iron and steelmaking areas and a background site at Ningbo Nottingham University (UN) were selected in this study. The four steel plants were located in cities of Kunming (KM), Wuhan (WH), Nanjing (NJ) and Ningbo (NB), China (Fig. 1). Their background information, including population and meteorological data at each sampling site, are detailed in Table 1.

The steel plant at KM was built in 1939, which was the oldest facility among the sampled areas. There were three blast oxygen furnaces (BOFs) and one blast furnace (BF) at KM plant with iron and steel production of seven million tonnes per year. Steel plants located at WH and NJ were both built in 1958. The WH plant had an annual production of iron and steel up to 20 million tonnes with eight BFs and ten
BOFs facilities, while the NJ plant produced 9 million tonnes of iron and steel every year with five BFs, six BOFs and one electric arc furnace (EAF). The NB plant was established in 2003 equipped with two BFs and three BOFs with an annual iron and steel production of 4 million tonnes.

\section{Sample Collection}

Air filter samples at each sampling site were collected at local meteorological sites or on the roof of high buildings at less than $1 \mathrm{~km}$ from the steelmaking emission sources. A non-viable Andersen cascade impactor with 8 aluminium state plates (Model 20-800, Tisch Environmental) was applied to collect atmospheric particles at five sampling sites. The $50 \%$ cut off diameters $\left(D_{50}\right)$ of the Andersen sampler stages were 9.0, 5.8, 4.7, 3.3, 2.1, 1.1, 0.65 and $<0.43 \mu \mathrm{m}$. The air flow was set up at $28.3 \mathrm{~L} \mathrm{~min}^{-1}$ for 24 hours during sampling with similar environmental and meteorological conditions. All samples were stored at $4^{\circ} \mathrm{C}$ until analysis.

\section{Sample Analysis}

Air filter samples were subjected to trace element analysis of As, $\mathrm{Ba}, \mathrm{Cd}, \mathrm{Cr}, \mathrm{Cu}, \mathrm{Mn}, \mathrm{Pb}, \mathrm{Sb}, \mathrm{V}$ and $\mathrm{Zn}$ at the National Measurement Institute in Sydney using an inductively coupled plasma mass spectrometer (Agilent 7900).

Every sample batch $(n=20)$ included a filter blank and duplicate, blank spike, blank matrix and matrix spikes. Procedural blanks were below the Limit of Reporting of $<0.01 \mathrm{mg} \mathrm{kg}^{-1}$ for As, Ba, Cd, Cr, Cu, Mn, Pb, Sb, V and $\mathrm{Zn}$. Recovery rates for $\mathrm{As}, \mathrm{Ba}, \mathrm{Cd}, \mathrm{Cr}, \mathrm{Cu}, \mathrm{Mn}, \mathrm{Pb}, \mathrm{Sb}, \mathrm{V}$ and $\mathrm{Zn}$ ranged between 95 and $106 \%$ for all PM samples. The results on the concentration of each metal in the collected particle size ranges for the sampling sites are detailed by Yang et al. (2019).

\section{Environmental Impact Assessment}

Life Cycle Impact Assessment (LCIA) methods are used to establish a link between emissions produced during

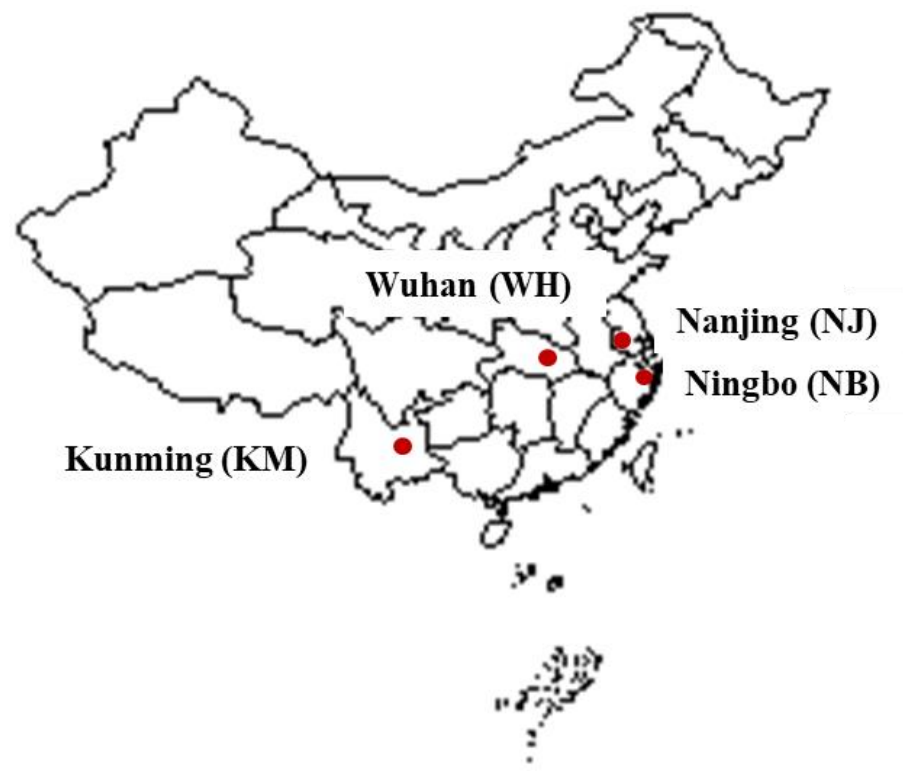

Fig. 1. Sampling locations in this study. 
Table 1. Background information at sampling cities Kunming (KM), Wuhan (WH), Nanjing (NJ) and Ningbo (NB). Population data was obtained from National Bureau of Statistics of China in 2017. The meteorological information during sampling period was obtained from China National Environmental Monitoring Centre.

\begin{tabular}{|c|c|c|c|c|c|c|c|c|}
\hline Cities & $\begin{array}{l}\text { Population } \\
\text { (million) }\end{array}$ & Sampling date & $\begin{array}{l}\mathrm{PM}_{2.5} \\
\left(\mu \mathrm{g} \mathrm{m}^{-3}\right)\end{array}$ & $\begin{array}{l}\mathrm{PM}_{10} \\
\left(\mu \mathrm{g} \mathrm{m}^{-3}\right)\end{array}$ & $\begin{array}{l}\text { Relatively } \\
\text { humidity } \\
(\%)\end{array}$ & $\begin{array}{l}\text { Temperature } \\
\left({ }^{\circ} \mathrm{C}\right)\end{array}$ & $\begin{array}{l}\text { Wind } \\
\text { speed } \\
\left(\mathrm{m} \mathrm{s}^{-1}\right)\end{array}$ & $\begin{array}{l}\text { Precipitation } \\
(\mathrm{mm})\end{array}$ \\
\hline & & & \multicolumn{6}{|c|}{ Min-max } \\
\hline KM & 5.6 & $2017 / 04 / 29-05 / 05$ & $22-38$ & $63-95$ & -- & $10-26$ & $0.2-2.9$ & 0 \\
\hline WH & 8.5 & $2017 / 05 / 14-05 / 20$ & $41-75$ & $89-163$ & $49-100$ & $18-33$ & $0.1-4.6$ & 5.6 \\
\hline $\mathrm{NJ}$ & 6.8 & 2017/05/28-06/04 & $25-72$ & $77-118$ & $21-86$ & $19-34$ & $0.2-6.8$ & 0 \\
\hline NB & 6.0 & $\begin{array}{l}2017 / 06 / 13-06 / 19 ; \\
2017 / 06 / 29-07 / 01^{\mathrm{a}}\end{array}$ & $13-35$ & $18-65$ & $49-96$ & $17-28$ & $0.1-6.4$ & $67^{\mathrm{a}}$ \\
\hline & & $2017 / 05 / 17-05 / 23^{\mathrm{b}}$ & & & & & & $0^{\mathrm{b}}$ \\
\hline
\end{tabular}

a. sampling period near iron and steelmaking area.

b. sampling period on UN campus.

--no available data.

manufacturing process and their potential environmental impacts. In this study, the OpenLCA 1.9.0 software was applied to assess environmental impacts caused by toxic metals in particulate matter collected near iron and steelmaking areas in China. PM metal concentrations at fractions $\mathrm{PM}_{2.1-9.0}$, $\mathrm{PM}_{1.1-2.1}$, and $\mathrm{PM}_{1.1}$ were input parameters as the End-ofLife modelling for $1 \mathrm{~m}^{3}$ of air as a reference flow property.

The ReCiPe Midpoint LCIA method was used for the present study to evaluate freshwater ecotoxicity, terrestrial ecotoxicity, marine ecotoxicity and human toxicity at high population densities. The fate and effects of metal emissions were expressed in $\mathrm{kg}$ 1,4-dichlorobenzene-equivalents $(1,4-$ DB eq) in the midpoint assessment, which were calculated by the OpenLCA software.

\section{RESULTS AND DISCUSSION}

The PM particles collected in this study were subjected to mass concentration analysis to investigate the distribution of particle sizes emitted from iron and steelmaking plants in China. The study further applied the environmental impact assessment to determine the risks of PM particles presented across the four categories from surface freshwater, terrestrial and marine ecotoxicity to human health.

\section{Mass Concentrations}

The mass concentrations at fractions of $\mathrm{PM}_{1.1}, \mathrm{PM}_{1.1-2.1}$ and $\mathrm{PM}_{2.1-9.0}$ are detailed in Fig. 2, and the public air quality data $\left(\mathrm{PM}_{2.5}\right.$ and $\left.\mathrm{PM}_{10}\right)$ derived from China National Environmental Monitoring Centre (CNEMC) are compiled in Table 1.

According to the CNEMC air quality data, the air quality index (AQI) at the sampling site KM was 'Good' (AQI = 51-100) with $\mathrm{PM}_{2.5}$ and $\mathrm{PM}_{10}$ concentrations ranging from 22-38 $\mu \mathrm{g} \mathrm{m}^{-3}$ and 63-95 $\mu \mathrm{g} \mathrm{m}^{-3}$, respectively (Table 1). However, mass concentrations of $\mathrm{PM}_{1.1}\left(25-41 \mu \mathrm{g} \mathrm{m}^{-3}\right)$ and $\mathrm{PM}_{9.0}\left(83-145 \mu \mathrm{g} \mathrm{m}^{-3}\right)$ at $\mathrm{KM}$ measured in this study were higher than the CNEMC data. This was also found at NB site where the official AQI was 'Excellent' (AQI =0-50) with the minimum values of $\mathrm{PM}_{2.5}$ and $\mathrm{PM}_{10}$ at 13 and $18 \mu \mathrm{g} \mathrm{m}^{-3}$, respectively, while the sampling results presented in this study near the steel manufacturing area were 23 and $33 \mu \mathrm{g} \mathrm{m}^{-3}$ for $\mathrm{PM}_{2.1}$ and $\mathrm{PM}_{9.0}$, respectively. The elevated PM mass concentrations near iron and steel areas indicated the levels of impact of iron and steelmaking activities on local air pollution in China.

The results also showed that the mass concentration of the coarse PM fraction at 2.1-9.0 $\mu \mathrm{m}$ diameters at KM was significantly higher than other fractions (Fig. 2). This could be a result of the age of the steel plant at KM site, which has been operating for approximately 70 years and was equipped with limited particle control measures. The mass concentration of PM particles collected from $\mathrm{WH}$ and $\mathrm{NJ}$ had similar $\mathrm{PM}_{2.1-9.0}$ and $\mathrm{PM}_{1.1-2.1}$ fractions, but $\mathrm{NJ}$ had a slightly higher $\mathrm{PM}_{1.1}$ mass concentrations than WH. Steel plants at WH and NJ were both built in 1958 and have been upgraded several times during operation.

The three PM fractions collected at NB and UN sites had similar mass concentrations. Although NB site was located in an iron and steelmaking industrial area, PM samples were collected at upwind of emissions as the downwind was the East China Sea. The industrial steelmaking facility at the NB site was also of the most recent age with modern particle capture devices.

\section{Environmental Impact Assessment}

The environmental impact assessment categories investigated in this work using the measured trace metal concentrations for the three PM fractions are presented in Fig. 3. At the coarse fraction of $\mathrm{PM}_{2.1-9.0}$, the sampling site of $\mathrm{KM}$ showed the highest ecotoxicity for freshwater, terrestrial, marine and human, followed by WH, NJ, NB and UN for the same size fraction. This may be because the steelwork at the KM site is the oldest and may be a reflection of the age of the facility. The KM steelwork plant is also located next to a busy main road. According to the previous studies by Barmpadimos et al. (2011) and Charron and Harrison (2005), the traffic emissions related to tyre and brake abrasion were also a significant contributor to the coarse PM particles. Hence, the long running operation of KM plant and the surrounded heavy traffic dominated the coarse PM pollution at KM. 


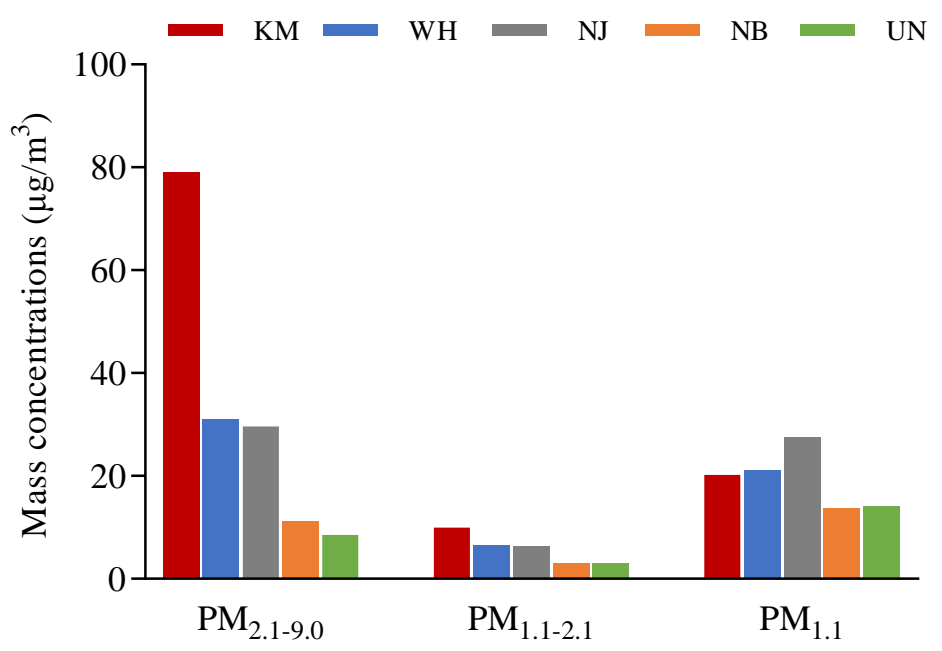

Fig. 2. Average mass concentrations $\left(\mu \mathrm{g} \mathrm{m}^{-3}\right)$ at fractions of $\mathrm{PM}_{2.1-9.0}, \mathrm{PM}_{1.1-2.1}$ and $\mathrm{PM}_{1.1}$ across five sampling sites.

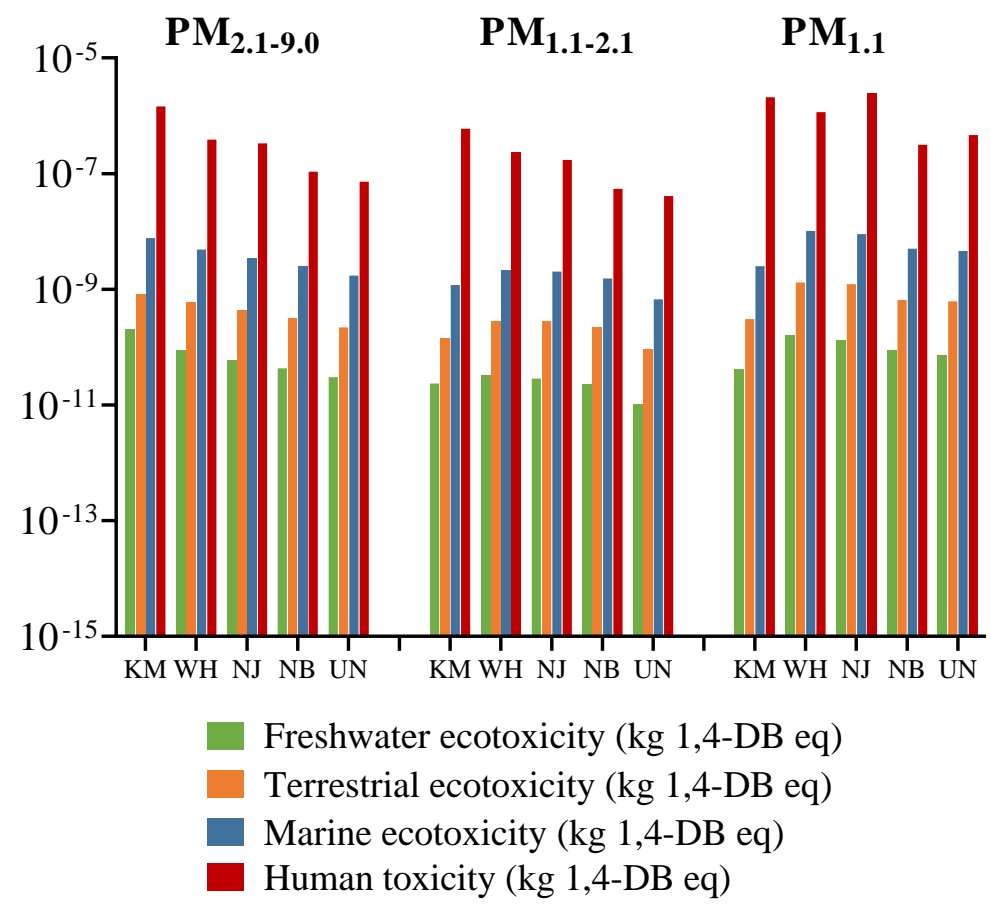

Fig. 3. Life cycle impact assessment of metal concentrations at fractions of $\mathrm{PM}_{2.1-9.0}, \mathrm{PM}_{1.1-2.1}$ and $\mathrm{PM}_{1.1}$.

The same order of $\mathrm{KM}>\mathrm{WH}>\mathrm{NJ}>\mathrm{NB}>\mathrm{UN}$ at $\mathrm{PM}_{2.1-9.0}$ fractions was also found for the intermodal fraction of $\mathrm{PM}_{1.1-2.1}$ for the human toxicity (Fig. 3). However, the maximum freshwater, marine and terrestrial ecotoxicity were found at the WH site where the steelwork plant was built in 1958 and had the largest annual iron and steel production of 20 million tonnes among the four investigated steelworks.

The fine $\mathrm{PM}_{1.1}$ particles at $\mathrm{WH}, \mathrm{NJ}, \mathrm{NB}$ and $\mathrm{UN}$ had higher values in the categories of freshwater ecotoxicity, terrestrial ecotoxicity, marine ecotoxicity and human toxicity than their corresponding $\mathrm{PM}_{1.1-2.1}$ and $\mathrm{PM}_{2.1-9.0}$ fractions at each site. This is because small particles tend to be more polluted with heavy metals, due to the nucleation and coagulation mode of particle formation mechanisms, than the intermodal and especially the coarse fractions, where the mechanically generated particles dominate (Samara and Voutsa, 2005; Hassanvand et al., 2015). Furthermore, $\mathrm{PM}_{1.1}$ particles can travel up to tens of kilometres in the atmosphere (WHO, 2006), posing a significant ecological risk as well as carcinogenic and mutagenic respiratory risks to humans over a large geographical area (Saeedi et al., 2012; Zajusz-Zubek et al., 2017).

\section{Freshwater Ecotoxicity}

The maximum freshwater ecotoxicity was found to be caused by $\mathrm{PM}_{2.1-9.0}$ contamination at the $\mathrm{KM}$ steelmaking site (Fig. 4). The largest contributor to freshwater ecotoxicity at $\mathrm{PM}_{2.1-9.0}$ was $\mathrm{V}$ with $55 \%$ contribution, followed by $\mathrm{Cu}$ with $26 \%$, while the contribution of other elements to the freshwater ecotoxicity ranged from $0.05 \%$ to $6.6 \%$ (Fig. 4). 
Previous studies showed that $\mathrm{V}$ contamination at coarse particles was used as an indicator of diesel combustion (Onat et al., 2013; Wei et al., 2014; Ogundele et al., 2016). Hence, the traffic in addition to the local steelmaking activities were the dominant sources resulting in the freshwater ecotoxicity at the KM sampling site.

In addition to $\mathrm{KM}$, the freshwater ecotoxicity at $\mathrm{WH}, \mathrm{NJ}$, $\mathrm{NB}$ and $\mathrm{UN}$ were largely contributed by $\mathrm{Cu}$ ranging from $45 \%$ to $77 \%$ followed by $\mathrm{Zn}$ ranging from $10 \%$ to $38 \%$ (Fig. 4). $\mathrm{Cu}$ and $\mathrm{Zn}$ contamination have been observed to play a significant negative role in the diversity and trophic structure of the biological communities, such as freshwater mussel and algae in the aquatic systems (Wilde et al., 2006; Wang et al., 2010; Wright et al., 2018).

\section{Terrestrial Ecotoxicity}

The largest terrestrial ecotoxicity was found in the $\mathrm{PM}_{1.1}$ particle size range at WH with $1.31 \mathrm{E}-09$ ( $\mathrm{kg} 1,4-\mathrm{DB}$ eq) (Fig. 5). The dominant contributor was $\mathrm{Cu}$ which was responsible for $72 \%$ of the terrestrial ecotoxicity at $\mathrm{WH}$. Compared to $\mathrm{PM}_{1.1}$ at $\mathrm{WH}, \mathrm{PM}_{1.1}$ at $\mathrm{NJ}$ posed a slightly lower terrestrial ecotoxicity dominated by $\mathrm{Zn}$ with $54 \%$ contribution (Fig. 5).

Higher Zn contribution for $\mathrm{PM}_{1.1}$ at site $\mathrm{NJ}$ compared to WH may be related to the differences in the steelmaking facilities. Steelwork plants at NJ and WH both have blast furnaces (BF) and blast oxygen furnaces (BOF) for steel production, but $\mathrm{NJ}$ plant has additional electric arc furnace (EAF) for processing of melting scrap for recycling of steel (Yang et al., 2019). It has been evidenced that EAF generates more $\mathrm{Zn}$ emissions than the BF-BOF route ( $8 \%$ vs. $19.4 \%$ ) (Nyirenda, 1991; Jha, 2001).

\section{Marine Ecotoxicity}

Similar to terrestrial ecotoxicity, $\mathrm{PM}_{1.1}$ at $\mathrm{WH}$ and $\mathrm{NJ}$ were found to contribute to higher marine ecotoxicity (Fig. 6). $\mathrm{Cu}$ in $\mathrm{PM}_{1.1}$ at $\mathrm{WH}$ and $\mathrm{NJ}$ contributed $76 \%$ and $45 \%$ of the total terrestrial ecotoxicity. In addition to $\mathrm{Cu}$, the $\mathrm{Zn}$ contamination in $\mathrm{PM}_{1.1}$ was responsible for $19 \%$ and $46 \%$ of marine ecotoxicity at $\mathrm{WH}$ and $\mathrm{NJ}$, respectively.

Both $\mathrm{Cu}$ and $\mathrm{Zn}$ are essential elements with functions in oxygen transport (e.g., Cu) (Kim et al., 2008) and enzyme co-factors or metalloenzymes (e.g., $\mathrm{Cu}$ and $\mathrm{Zn}$ ) (Soetan et al., 2010). However, elevated $\mathrm{Cu}$ and $\mathrm{Zn}$ concentrations can result in marine pollution, damaging the quality of sediments (Miller et al., 2000) and posing a risk to marine animals (Lavery et al., 2009) and other organisms (Debelius et al., 2009).

\section{Human Toxicity}

$\mathrm{PM}_{1.1}$ had significantly higher human toxicity than the corresponding fractions of $\mathrm{PM}_{1.1-2.1}$ and $\mathrm{PM}_{2.1-9.0}$ at the five sampling sites (Fig. 7). PM emissions at the three size fractions in $\mathrm{KM}, \mathrm{WH}$ and $\mathrm{NJ}$ posed higher health risks to humans than UN as a background site and NB site which has a flue gas recirculation system with $45 \%$ reduction of PM emissions during the steelmaking process (CEIA, 2017).

The human toxicity of PM emissions was dominated by $\mathrm{Pb}$ contamination, especially for the fine $\mathrm{PM}_{1.1}$ particles. For example, the contribution of $\mathrm{Pb}$ on human toxicity of $\mathrm{PM}_{1.1}$ size fraction for sites $\mathrm{KM}$ and $\mathrm{NJ}$ was up to $87 \%$ and $76 \%$, respectively (Fig. 7). Airborne $\mathrm{Pb}$ emissions have cumulative toxic impacts on humans and adversely affect the neurological, hematological, gastrointestinal, cardiovascular and renal systems (U.S. EPA, 2017). As a result, around 0.6\% of the global burden of disease is estimated to be associated with exposure to $\mathrm{Pb}$ (WHO, 2010b).

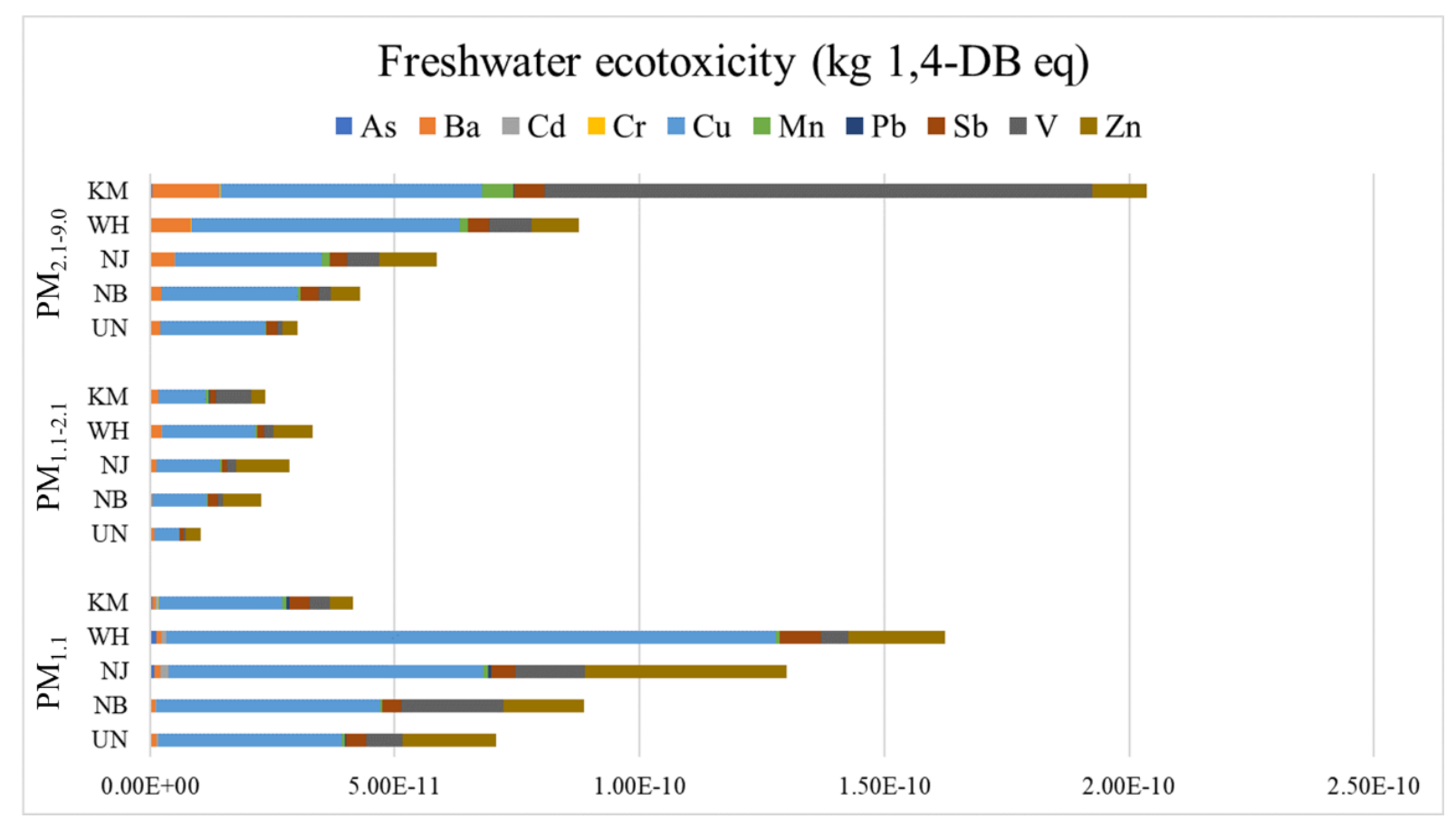

Fig. 4. Life cycle impact assessment of freshwater ecotoxicity based on metal concentrations at fractions of $\mathrm{PM}_{2.1-9.0}, \mathrm{PM}_{1.1-2.1}$ and $\mathrm{PM}_{1.1}$. 


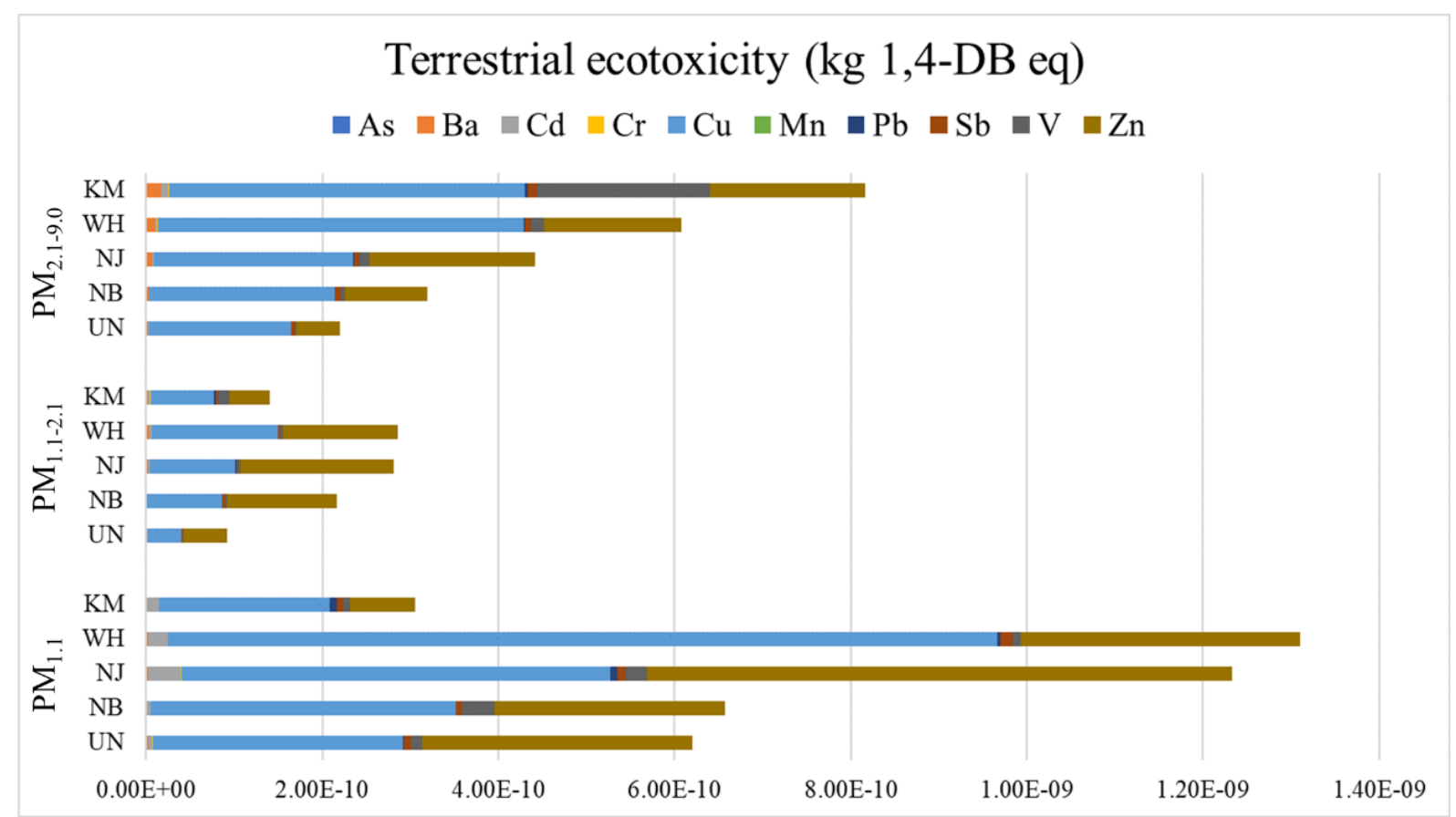

Fig. 5. Life cycle impact assessment of terrestrial ecotoxicity based on metal concentrations at fractions of $\mathrm{PM}_{2.1-9.0}, \mathrm{PM}_{1.1-2.1}$ and $\mathrm{PM}_{1.1}$.

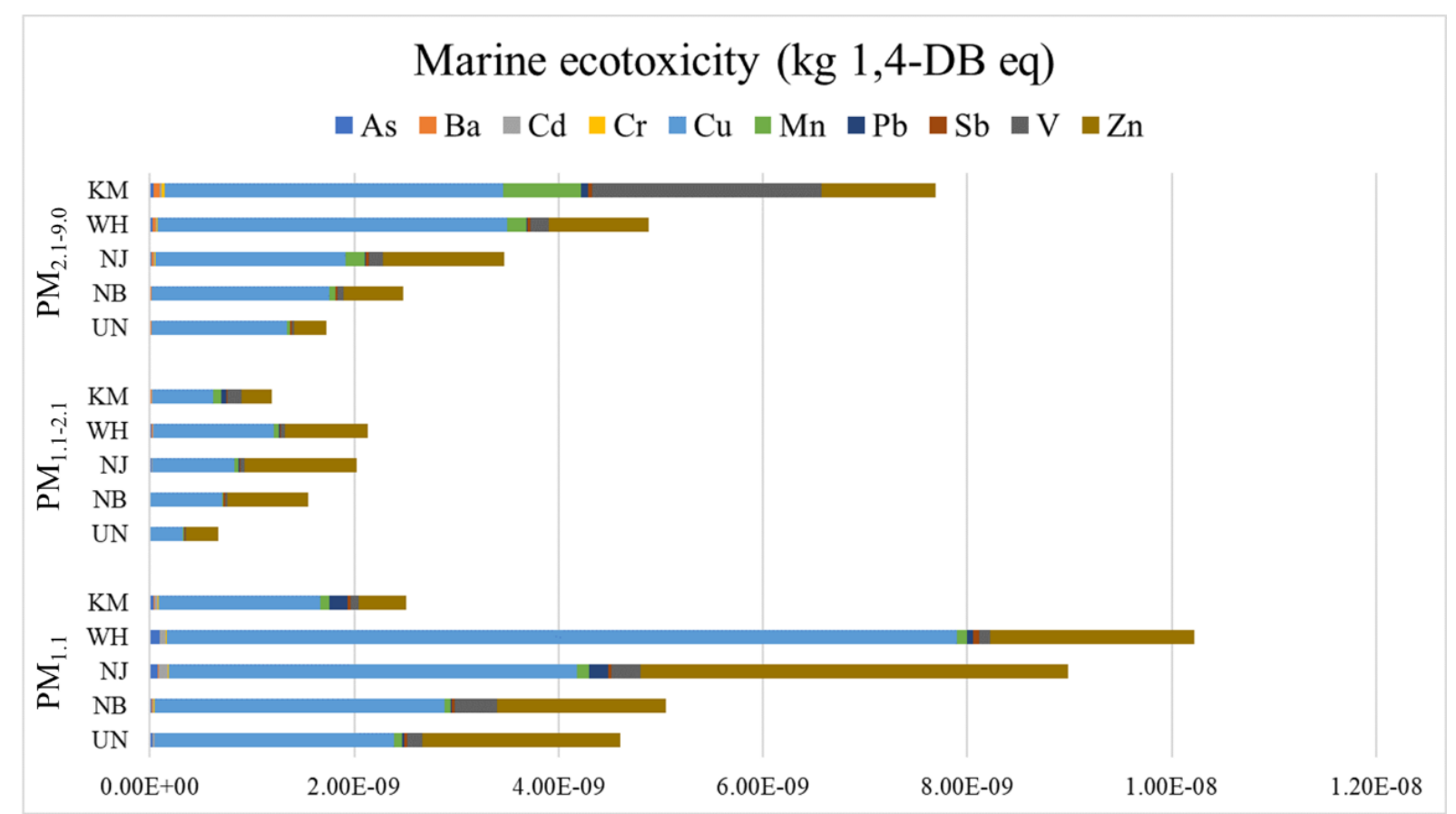

Fig. 6. Life cycle impact assessment of marine ecotoxicity based on metal concentrations at fractions of $\mathrm{PM}_{2.1-9.0}, \mathrm{PM}_{1.1-2.1}$ and $\mathrm{PM}_{1.1}$.

The contributions of As contamination to human toxicity were stable at the three size fractions which were $8 \%-19 \%$ at $\mathrm{PM}_{2.1-9.0}, 6 \%-26 \%$ at $\mathrm{PM}_{1.1-2.1}$ and $6 \%-26 \%$ at $\mathrm{PM}_{1.1}$ particles. Long-term exposure to airborne As emissions can increase the risks of developing lung cancer, especially at fine particles of $\mathrm{PM}_{1.1}$ which can penetrate deep into the alveolar regions of the human lungs (WHO, 2010a; Poh et al., 2018).

In addition to $\mathrm{As}$ and $\mathrm{Pb}$ contamination, airborne $\mathrm{Mn}$ was responsible for $2 \%-11 \%$ of human toxicity at $\mathrm{PM}_{1.1}$, but increased to $8 \%-18 \%$ at $\mathrm{PM}_{1.1-2.1}$ and reached maximum contribution of $23 \%-34 \%$ at $\mathrm{PM}_{2.1-9.0}$ size fractions. Unlike As and $\mathrm{Pb}$, which are classified as carcinogenic to humans (Group 1) and possibly carcinogenic to humans (Group 2A), 


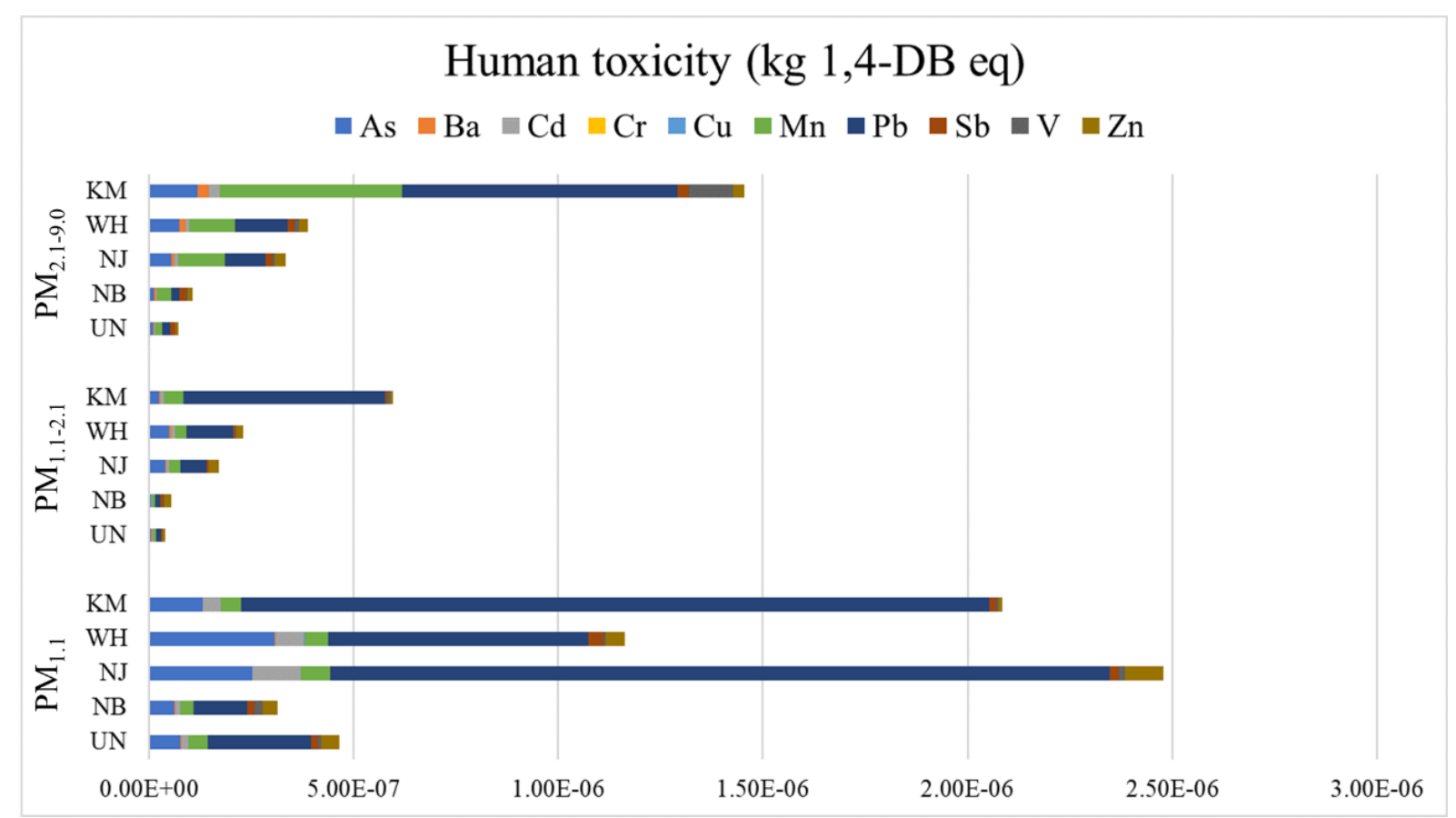

Fig. 7. Life cycle impact assessment of human toxicity based on metal concentrations at fractions of $\mathrm{PM}_{2.1-9.0}, \mathrm{PM}_{1.1-2.1}$ and $\mathrm{PM}_{1.1}$.

respectively (WHO, 2010a, b), Mn is considered as a nutritional element under a safe limit (ATSDR, 2012). However, exceeding $\mathrm{Mn}$ concentrations can cause environmental implications with potential risks to human health (Elder et al., 2006), especially for the children population. A number of studies documented the neurotoxic effects of Mn associated with learning disabilities and deficits in intellectual functions of children (Riojas-Rodriguez et al., 2010).

\section{CONCLUSION}

This study aimed to investigate the contamination of PM particles near iron and steelmaking areas in China. PM samples at ranges of less than $1.1 \mu \mathrm{m}, 1.1-2.1 \mu \mathrm{m}$ and $2.1-$ $9.0 \mu \mathrm{m}$ in diameter were collected in this study. All the samples were subject to mass concentration and trace element analyses. LCIA method was used to assess the impact of trace element contamination at different PM fractions on human and ecological health.

The mass concentration results showed that PM samples collected from intensive iron and steelmaking areas were higher than those collected from background areas and the published $\mathrm{PM}_{2.5}$ and $\mathrm{PM}_{10}$ data online at each city, confirming the industrial emission played a significant role to the local air quality. The LCIA results showed that PM metal emission had a much higher human toxicity than freshwater, terrestrial and marine ecotoxicity. Among the three PM fractions, $\mathrm{PM}_{1.1}$ particles posed significantly higher risks to both human and ecosystem health than the other two fractions. This study further revealed that the $\mathrm{Cu}$ and $\mathrm{Zn}$ contamination were the key contributors to freshwater, marine and terrestrial ecotoxicity, while $\mathrm{Pb}$ was the dominant contributor to human toxicity. Findings presented in this study provide a potential guideline to help the steel mills make effective actions to control the key toxic metals present in the PM emissions, improving the local environmental quality and reducing the risks to public health.

\section{REFERENCES}

Agency for Toxic Substances and Disease Registry (ATSDR) (2012). Public health statement for manganese, https://www.atsdr.cdc.gov/phs/phs.asp?id=100\&tid=23

Barmpadimos, I., Nufer, M., Oderbolz, D.C., Keller, J., Aksoyoglu, S., Hueglin, C., Baltensperger, U. and Prévôt, A.S.H. (2011). The weekly cycle of ambient concentrations and traffic emissions of coarse $\left(\mathrm{PM}_{10}-\mathrm{PM}_{2.5}\right)$ atmospheric particles. Atmos. Environ. 45: 4580-4590. https://doi.org/ 10.1016/j.atmosenv.2011.05.068

Borggaard, O.K., Hansen, H.C.B., Holm, P.E., Jensen, J.K., Rasmussen, S.B., Sabiene, N., Steponkaite, L. and Strobel, B.W. (2009). Experimental assessment of using soluble humic substances for remediation of heavy metal polluted soils. Soil Sediment Contam. 18: 369-382. https://doi.org/10.1080/15320380902799326

Calderon, J., Navarro, M.E., Jimenez-Capdeville, M.E., Santos-Diaz, M.A., Golden, A., Rodriguez-Leyva, I., Borja-Aburto, V. and Diaz-Barriga, F. (2001). Exposure to arsenic and lead and neuropsychological development in Mexican children. Environ. Res. 85: 69-76. https://doi. org/10.1006/enrs.2000.4106

Charron, A. and Harrison, R.M. (2005). Fine $\left(\mathrm{PM}_{2.5}\right)$ and coarse $\left(\mathrm{PM}_{2.5-10}\right)$ particulate matter on a heavily trafficked London highway: Sources and processes. Environ. Sci. Technol. 30: 7768-7776. https://doi.org/10.1021/es050462i Cheng, F.J., Lee, K.H., Lee, C.W. and Hsu, P.C. (2019). 
Association between particulate matter air pollution and hospital emergency room visits for pneumonia with septicemia: A retrospective analysis. Aerosol Air Qual. Res. 19: 345-354. https://doi.org/10.4209/aaqr.2018.08. 0285

China Environmental Impact Assessment (CEIA) (2017). Methods and strategies to reduce emissions of atmospheric particles in iron and steelmaking indutries. China Environmental Impact Assessment, Ministry of Ecology and Environment of the People's Republic of China. p. 73.

Debelius, B., Forja, J.M., DelValls, A. and Lubian, L.M. (2009). Toxicity and bioaccumulation of copper and lead in five marine microalgae. Ecotoxicol. Environ. Saf. 72: 1503 1513. https://doi.org/10.1016/j.ecoenv.2009.04.006

Elder, A., Gelein, R., Silva, V., Feikert, T., Opanashuk, L., Carter, J., Potter, R., Maynard, A., Ito, Y., Finkelstein, J. and Oberdorster, G. (2006). Translocation of inhaled ultrafine manganese oxide particles to the central nervous system. Environ. Health Perspect. 114: 1172-1178. https://doi.org/10.1289/ehp.9030

Hassanvand, M.S., Naddafi, K., Faridi, S., Nabizadeh, R., Sowlat, M.H., Momeniha, F., Gholampour, A., Arhami, M., Kashani, H., Zare, A., Niazi, S., Rastkari, N., Nazmara, S., Ghani, M. and Yunesian, M. (2015). Characterization of PAHs and metals in indoor/outdoor $\mathrm{PM}_{10} / \mathrm{PM}_{2.5} / \mathrm{PM}_{1}$ in a retirement home and a school dormitory. Sci. Total Environ. 527-528: 100-110. https://doi.org/10.1016/j.sc itotenv.2015.05.001

Jha, M.K. (2001). Review of hydrometallurgical recovery of zinc from industrial wastes. Resour. Conserv. Recy. 33: 1-22. https://doi.org/10.1016/S0921-3449(00)00095-1

Jiang, N., Liu, X., Wang, S., Yu, X., Yin, S., Duan, S., Wang, S., Zhang, R. and Li, S. (2019). Pollution characterization, source identification, and health risks of atmospheric-particle-bound heavy metals in $\mathrm{PM}_{10}$ and $\mathrm{PM}_{2.5}$ at multiple sites in an emerging megacity in the central region of China. Aerosol Air Qual. Res. 19: 247 271. https://doi.org/10.4209/aaqr.2018.07.0275

Kim, B.E., Nevitt, T. and Thiele, D.J. (2008). Mechanisms for copper acquisition, distribution and regulation. Nat. Chem. Biol. 4: 176-185. https://doi.org/10.1038/nchemb io. 72

Lavery, T.J., Kemper, C.M., Sanderson, K., Schultz, C.G., Coyle, P., Mitchell, J.G. and Seuront, L. (2009). Heavy metal toxicity of kidney and bone tissues in South Australian adult bottlenose dolphins (Tursiops aduncus). Mar. Environ. Res. 67: 1-7. https://doi.org/10.1016/j.mar envres.2008.09.005

Liu, J., Zheng, B.S., Aposhian, H.V., Zhou, Y.S., Chen, M.L., Zhang, A.H. and Waalkes, M.P. (2002). Chronic arsenic poisoning from burning high-arsenic-containing coal in Guizhou, China. Environ. Health Perspect. 110: 119-122. https://doi.org/10.1289/ehp.02110119

Miller, B.S., Pirie, D.J. and Redshaw, C.J. (2000). An assessment of the contamination and toxicity of marine sediments in the Holy Loch, Scotland. Mar. Pollut. Bull. 40: 22-35. https://doi.org/10.1016/S0025-326X(99)00190-3

Mohiuddin, K., Strezov, V., Nelson, P.F. and Stelcer, E. (2014). Characterisation of trace metals in atmospheric particles in the vicinity of iron and steelmaking industries in Australia. Atmos. Environ. 83: 72-79. https://doi.org/ 10.1016/j.atmosenv.2013.11.011

Mohiuddin, K., Strezov, V., Nelson, P.F. and Evans, T. (2016). Bonding structure and mineral analysis of size resolved atmospheric particles nearby steelmaking industrial sites in Australia. Aerosol Air Qual. Res. 16: 1638-1650. https://doi.org/10.4209/aaqr.2015.02.0076

Nyirenda, R.L. (1991). The processing of steelmaking fluedust: A review. Miner. Eng. 4: 1003-1025. https://doi.org /10.1016/0892-6875(91)90080-F

Ogundele, L.T., Owoade, O.K., Olise, F.S. and Hopke, P.K. (2016). Source identification and apportionment of $\mathrm{PM}_{2.5}$ and $\mathrm{PM}_{2.5-10}$ in iron and steel scrap smelting factory environment using PMF, PCFA and UNMIX receptor models. Environ. Monit. Assess. 188: 574. https://doi.org/ 10.1007/s10661-016-5585-8

Onat, B., Sahin, U.A. and Akyuz, T. (2013). Elemental characterization of $\mathrm{PM}_{2.5}$ and $\mathrm{PM}_{1}$ in dense traffic area in Istanbul, Turkey. Atmos. Pollut. Res. 4: 101-105. https://doi.org/10.5094/APR.2013.010

Poh, T.Y., Ali, N., Mac Aogain, M., Kathawala, M.H., Setyawati, M.I., Ng, K.W. and Chotirmall, S.H. (2018). Inhaled nanomaterials and the respiratory microbiome: Clinical, immunological and toxicological perspectives. Part. Fibre Toxicol. 15: 46. https://doi.org/10.1186/s129 89-018-0282-0

Riojas-Rodriguez, H., Solis-Vivanco, R., Schilmann, A., Montes, S., Rodriguez, S., Rios, C. and Rodriguez-Agudelo, Y. (2010). Intellectual function in Mexican children living in a mining area and environmentally exposed to manganese. Environ. Health Perspect. 118: 1465-1470. https://doi.org/10.1289/ehp.0901229

Saeedi, M., Li, L.Y. and Salmanzadeh, M. (2012). Heavy metals and polycyclic aromatic hydrocarbons: Pollution and ecological risk assessment in street dust of Tehran. $J$. Hazard. Mater. 227-228: 9-17. https://doi.org/10.1016/j. jhazmat.2012.04.047

Samara, C. and Voutsa, D. (2005). Size distribution of airborne particulate matter and associated heavy metals in the roadside environment. Chemosphere 59: 1197-1206. https://doi.org/10.1016/j.chemosphere.2004.11.061

Sarkodie, S.A., Strezov, V., Jiang, Y. and Evans, T. (2019). Proximate determinants of particulate matter $\left(\mathrm{PM}_{2.5}\right)$ emission, mortality and life expectancy in Europe, Central Asia, Australia, Canada and the US. Sci. Total Environ. 683: 489-497. https://doi.org/10.1016/j.scitoten v.2019.05.278

Semlali, R.M., Dessogne, J.B., Monna, F., Bolte, J., Azimi, S., Navarro, N., Denaix, L., Loubet, M., Chateau, C. and Van Oort, F. (2004). Modeling lead input and output in soils using lead isotopic geochemistry. Environ. Sci. Technol. 38: 1513-1521. https://doi.org/10.1021/es0341384

Soetan, K.O., Olaiya, C.O. and Oyewole, O.E. (2010). The importance of mineral elements for humans, domestic animals and plants-A review. Afr. J. Food Sci. 4: 200222. https://academicjournals.org/journal/AJFS/articleabstract/045441523024

Taylor, M.P., Isley, C.F. and Glover, J. (2019). Prevalence 
of childhood lead poisoning and respiratory disease associated with lead smelter emissions. Environ. Int. 127: 340-352. https://doi.org/10.1016/j.envint.2019.01.062

U.S. EPA (2016a). National Lakes Assessment 2012 Results, Washington, DC, p. 2.

U.S. EPA (2016b). National Rivers and Streams Assessment 2008-2009, Washington, DC, p. 2.

U.S. EPA (2017). Basic Information about Lead Air Pollution, https://www.epa.gov/lead-air-pollution/basicinformation-about-lead-air-pollution\#health

Wang, N., Ingersoll, C.G., Ivey, C.D., Hardesty, D.K., May, T.W., Augspurger, T., Roberts, A.D., van Genderen, E. and Barnhart, M.C. (2010). Sensitivity of early life stages of freshwater mussels (Unionidae) to acute and chronic toxicity of lead, cadmium, and zinc in water. Environ. Toxicol. Chem. 29: 2053-2063. https://doi.org/10.1002/ etc. 250

Wasserman, G.A., Liu, X., Parvez, F., Factor-Litvak, P., Kline, J., Siddique, A.B., Shahriar, H., Uddin, M.N., van Geen, A., Mey, J.L., Balac, O. and Graziano, J.H. (2016). Child intelligence and reductions in water arsenic and manganese: A two-year follow-up study in Bangladesh. Environ. Health Perspect. 124: 1114-1120. https://doi.org /10.1289/ehp.1509974

Wei, Z., Wang, L.T., Chen, M.Z. and Zheng, Y. (2014). The 2013 severe haze over the Southern Hebei, China: PM$_{2.5}$ composition and source apportionment. Atmos. Pollut. Res. 5: 759-768. https://doi.org/10.5094/APR.2014.085

Wesely, M.L. and Hicks, B.B. (2000). A review of the current status of knowledge on dry deposition. Atmos. Environ. 34: 2261-2282. https://doi.org/10.1016/S13522310(99)00467-7

World Health Organization (WHO) (2006). Health risks of particulate matter from long-range transboundary air pollution. WHO Regional Office for Europe, Copenhagen, p. 113. https://apps.who.int/iris/handle/10665/107691

World Health Organization (WHO) (2007). Health risks of heavy metals from long-range transboundary air pollution. WHO Regional Office for Europ, Copenhagen, p. 144. https://apps.who.int/iris/handle/10665/107872

World Health Organization (WHO) (2010a). Exposure to arsenic: A major public health concern. World Health Organization, Geneva, Switzerland.
World Health Organization (WHO) (2010b). Exposure to lead: A major public health concern. World Health Organization, Geneva, Switzerland, p. 6.

World Health Organization (WHO) (2013). Health effects of particulate matter - Policy implications for countries in eastern Europe, Caucasus And Central Asia. WHO Regional Office for Europe, Denmark, p. 20.

World Health Organization (WHO) (2018, May 2). Ambient (outdoor) air quality and health, https://www.who.int/newsroom/fact-sheets/detail/ambient-(outdoor)-air-quality-andhealth

Wilde, K.L., Stauber, J.L., Markich, S.J., Franklin, N.M. and Brown, P.L. (2006). The effect of $\mathrm{pH}$ on the uptake and toxicity of copper and zinc in a tropical freshwater alga (chlorella sp.). Arch. Environ. Contam. Toxicol. 51: 174185. https://doi.org/10.1007/s00244-004-0256-0

Wright, L.P., Zhang, L., Cheng, I., Aherne, J. and Wentworth, G.R. (2018). Impacts and effects indicators of atmospheric deposition of major pollutants to various ecosystems - A review. Aerosol Air Qual. Res. 18: 19531992. https://doi.org/10.4209/aaqr.2018.03.0107

Wright, R.O., Amarasiriwardena, C., Woolf, A.D., Jim, R. and Bellinger, D.C. (2006). Neuropsychological correlates of hair arsenic, manganese, and cadmium levels in school-age children residing near a hazardous waste site. Neurotoxicology 27: 210-216. https://doi.org/10.1016/j.n euro.2005.10.001

Yang, X., Zhou, X., Kan, T., Strezov, V., Nelson, P., Evans, T. and Jiang, Y. (2019) Characterization of size resolved atmospheric particles in the vicinity of iron and steelmaking industries in China. Sci. Total Environ. 694: 133534. https://doi.org/10.1016/j.scitotenv.2019.07.340

Zajusz-Zubek, E., Radko, T. and Mainka, A. (2017). Fractionation of trace elements and human health risk of submicron particulate matter $\left(\mathrm{PM}_{1}\right)$ collected in the surroundings of coking plants. Environ. Monit. Assess. 189: 389. https://doi.org/10.1007/s10661-017-6117-x

Received for review, October 31, 2019 Revised, December 10, 2019 Accepted, December 17, 2019 